\title{
Hazardous substances in the water, biota and sediments of the North Estonian coastal sea
}

\author{
O. Roots ${ }^{1,2} \&$ Ü. Suursaar ${ }^{1}$ \\ ${ }^{1}$ Estonian Marine Institute, University of Tartu, Estonia \\ ${ }^{2}$ Estonian Environmental Research Centre, Estonia
}

\begin{abstract}
The paper gives an overview of Estonian experiences with hazardous substances monitoring, as well as some recent results on this kind of monitoring in the aquatic environment, biota and sediments of the heavily industrialized North Estonia. Owing to its specific local conditions, the present list of priority hazardous substances of Estonia includes 1- and 2-basic phenols, heavy metals $(\mathrm{Cr}, \mathrm{Cu}, \mathrm{Ni}, \mathrm{Zn})$ and persistent organic pollutants $(\mathrm{HCH}, \mathrm{HCB}, \mathrm{PCB}, \mathrm{DDT}$, PCDD, PCDF, DL-PCB). The concentrations of hazardous substances in the sea and surface waters are currently low, but elevated concentrations may appear in bottom sediments of river estuaries and in fat tissues of fish. During recent decades the state of the North Estonian environment regarding the hazardous substances has continuously improved due to a decreased pollution load, ban of certain compounds, self-purification processes and sinks.

Keywords: priority hazardous substances, POPs, monitoring, bioaccumulation, oil shale, Baltic Sea.
\end{abstract}

\section{Introduction}

The Action Plan of the Helsinki Commission (HELCOM) to reduce pollution of the Baltic Sea and restore its ecological status by 2020 was approved in November 2007 by representatives of all the nine countries surrounding the Baltic Sea. One of the four main topics, the hazardous substances segment, defines the main goals as follows: to reach the concentrations of hazardous substances close to background levels for naturally occurring substances, close to zero for manmade substances, have all fish become safe to eat and reach preChernobyl levels of radioactivity in the Baltic Sea ecosystem [1]. 
In the heavily industrialized northern part of Estonia, oil shale based chemical industry and power plants, cement and pulp mills, and a Soviet-era depository of radioactive wastes have seriously impacted virtually every component of the environment. It is also the major pollution source and a "hot spot" for the whole Baltic Sea environment [2,3]. Therefore, the main efforts in the monitoring of hazardous substances in Estonia have been concentrated into that area.

It is known that the list of modern time chemicals and ingredients, which could be viewed as pollutants, is enormously long. Some of the pollutants may be quite common in the environment (e.g. so-called nutrients, such as $\mathrm{N}$ and $\mathrm{P}$ salts, oils, heat) and become dangerous only due to excessive anthropogenic emissions. However, hardly degradable synthetic compounds can be hazardous even in very low concentrations. The main criteria for deciding their hazard are toxicity (both acute and chronic), persistency, bio-accumulating properties, and some other aspects (e.g. carcinogenic or synergic influences) [1,4]. As far as it is practically possible to monitor only selected substances, one should also estimate the amount of their emissions and spread.

The paper focuses mainly on the so-called toxic priority substances, which were initially listed in the Stockholm Convention and in UNEP 2003 protocols $[4,5]$. However, the list itself is constantly changing. Also, as far as both widespread and more local ingredients exist, each country has to identify their own versions of the list. In 1999-2001, three nation-wide inventories of hazardous substances were performed in Estonia. The protocols of UNEP require a ban or minimized use of these priority hazardous substances. Import of chlororganic pesticides to Estonia has been prohibited since 1967 and Estonia itself has not been manufacturing them. The rest of the obsolete pesticides have been disposed of in Estonia. However, both persistent organic pollutants (POPs) and heavy metals (HMs) still circulate in the environment and food webs. Discharges of certain compounds inevitably continue, although in reduced quantities, and new compounds are being synthesised. Therefore, the horizon of knowledge on that issue is also broadening and modifying.

The aims of the paper are to (1) give a brief overview of Estonian hazardous substances monitoring activities and corresponding environmental management, and (2) to summarise the results of the monitoring of hazardous substances in the water, biota and sediments of the North Estonian coastal environment.

\section{Material and methods}

\subsection{Historic overview of monitoring}

For analysis of water quality in the North Estonian coastal sea we used the monitoring databases of the Estonian Marine Institute and Estonian Environmental Research Centre. They include both the historical data over the period 1968-1993 [6,7], as well as the more recent data from the new revised national monitoring programme $[8,9]$.

Regular pollution control in some parts of the coastal waters of Estonia began in 1967, after the endorsement of the General Plan for Water Use and Protection 
of the USSR. Until 1991, the marine monitoring was carried out in about 40-50 stations by the former Estonian Hydrometeorological Service within the monitoring system of the Soviet Union. The variables measured included hydrological variables and nutrients, as well as oils, phenols, detergents, POPs, lignine, and some trace metals.

Starting from 1991, revision of the national monitoring began. Evaluation of the national monitoring data revealed excessive variability, systematic biases and incompatibility with other data sets due to different sampling and analysing standards [6]. The present programme is based on the requirements of the Baltic Monitoring Programme from 1998 (COMBINE), and the European Water Framework Directive. It includes several sub-programmes, one being the monitoring of priority hazardous substances in the marine environment, which is currently conducted by the Estonian Marine Institute.

\subsection{Material and methods for hazardous substances monitoring}

In Estonia, the concentrations of hazardous substances in the aquatic environment have been surveyed since 1974 [7,8]. Since then, both the list of substances monitored and the locations and environs have changed several times. As the concentrations of POPs in the coastal waters appeared mostly to be below detection level of the analytical methods of these days, the focus of the survey shifted to the selected fish species in the coastal sea and rivers. As far as many chemical contaminants become concentrated at the top of the food chain, such monitoring offers more stable values and an integrated view together with food safety issues.

Estonia specified its list of hazardous substances for surface water on national level proceeding from the directive 92/446/EEC of the European Council from 1992 and Commission decision 95/337/EC from 1995. At present, the list of priority hazardous substances of Estonia includes 1-basic phenols (p-, m- and ocresols; 2,3-, 2,6-, 3,4- and 3,5-dimethylphenols), 2-basic phenols (resorcinol, 5methyl resorcinol and 2,5-dimethyl resorcinol), $\mathrm{Ba}$ (only in Vend-layer groundwater), heavy metals $(\mathrm{Cr}, \mathrm{Cu}, \mathrm{Ni}, \mathrm{Zn})$ together with their compounds and persistent organic pollutants (HCH, HCB, PCB, DDT, PCDD, PCDF, DL-PCB) [10]. Chlororganic substances in certain fish and mollusc (Macoma, Saduria) species are sampled annually in three monitoring clusters (in the bays of Pärnu, Tallinn and Kunda). According to HELCOM recommendations, the selected bioindicator is the female Baltic herring of two-three years age [11]. In selected North Estonian rivers, samples of fishes (or sediments, in case of intakes) are performed. The method of so-called rotation monitoring is used. I.e., not all of the substances and locations are monitored each year.

Most of the water and sediment samples have been taken by employees of the Estonian Environmental Research Centre (EERC), which also made the most laboratory tests. The Estonian Accreditation Centre certifies that EERC has competence according to ISO/IEC 17025:2005 to conduct tests in the field of water, soil, food, air and petroleum product analyses [8]. More detailed description of sampling techniques as well as analytical procedures can be found in [12-14]. The biota samples have been taken by employees of Estonian Marine 
Institute and some water samples from North-Estonian rivers and estuaries by Tallinn Technological University [15]. The analyses for polychlorinated dibenzo-p-dioxins (PCDDs), polychlorinated dibenzofurans (PCDFs) and dioxinlike polychlorinated biphenyls (DL-PCBs) were ordered from Finland.

\section{Study area}

The North Estonian coastal sea stretches for about $300 \mathrm{~km}$ from west to east along the Gulf of Finland (Fig. 1), which has an area of $29500 \mathrm{~km}^{2}$ and average depth of $37 \mathrm{~m}$. The Gulf receives a relatively large pollution load both from rivers (Neva, Narva, Kymijoki), as well as from industries and municipalities $[2,3]$. The circulation scheme in the Gulf of Finland is mostly wind-driven and although certain statistical long-term patterns can be found [16], it is quite variable in time and space. The northern coast of Estonia has a relatively straight coastline where good mixing conditions due to waves and currents prevail [17].

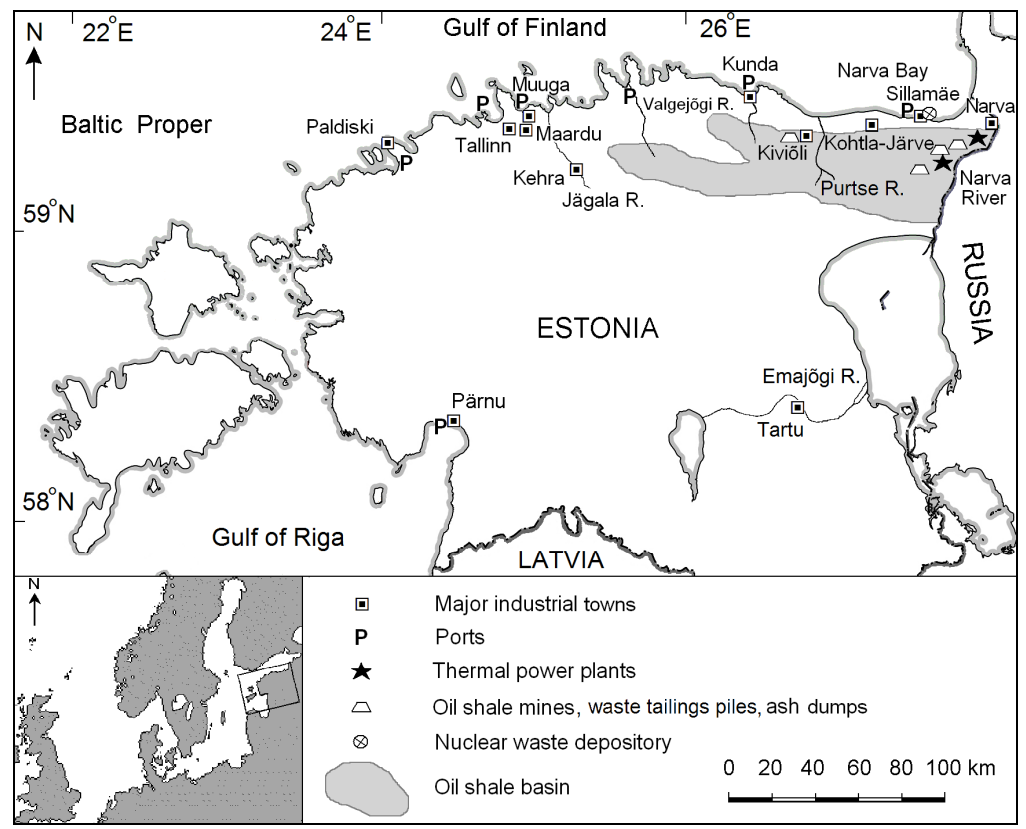

Figure 1: The study area: North Estonian industrial zone and the coastal sea.

As natural degradation of hazardous substances is low, the main losses occur via sinks to bottom sediments, fish catches, as well as by simple dilution and spread over larger areas, (if the concentrations are lower there). On the other hand, the persistent pollutants can also be brought to the site by rivers, seacurrents and atmospheric deposition.

Bearing in mind the fact that the most of the Baltic Sea organisms live at the edge of their physiological tolerance range, anthropogenic chemical pollution has 
to be seen as a further stress factor acting upon marine biodiversity. Although some blue-green algae produce natural toxins in substantial quantities, which can affect, for instance, reproduction and growth of fish [18], the anthropogenic (synthetic) toxic and hazardous substances vastly dominate in the marine environment. Despite the recent reduction in pollution load and good hydrodynamic dilution conditions, the area has not yet fully recovered from the past anthropogenic pressure [2] and some persistent compounds are bioaccumulated in the biota and bottom sediments $[4,11]$.

\section{The main pollution sources}

Oil shale mining and oil shale-based power and chemical industry has been the main cornerstone of the Estonian economy for decades. On the other hand, it is also the largest source of pollution. Estonian oil shale (kukersite) reserves are vast (Table 1$)$. The majority of the mined oil shale (10-15 million tons/yr) is used for electricity generation in two thermal power plants near Narva and Kohtla-Järve with total capacity of $2.4 \mathrm{MW}$ (Fig. 1). As oil shale is a low-grade fossil fuel, each year about 4-5 million tons of oil shale ash and semi-coke is dumped near the power plants, where residual organic matter is prone to selfignition and give gaseous emissions (e.g. $\mathrm{SO}_{2}, \mathrm{NOx}$ ), and influencing also rivers of Narva, Purtse, Valgejõgi and Jägala (Fig. 1).

For the coastal sea, however, the main risks appear from the effluents of oil shale-based chemical industry and oil extraction. During the economic peak of 1980s, Kohtla-Järve and Kiviõli chemical companies discharged substantial amounts of phenols $(650 \mathrm{t} / \mathrm{yr})$, oils, and different hazardous substances to the rivers and coastal sea $[2,3,15]$.

Table 1: $\quad$ Resources and extraction of Estonian oil shale in million tons [19].

\begin{tabular}{|c|c|c|c|c|}
\hline \multicolumn{2}{|c|}{ Extraction } & \multicolumn{3}{|c|}{ Reserves and resources (2007) } \\
\hline 2005 & 2006 & $\begin{array}{c}\text { Proved mineable } \\
\text { reserves }\end{array}$ & $\begin{array}{c}\text { Inferred mineable } \\
\text { resources }\end{array}$ & $\begin{array}{c}\text { Sub-marginal } \\
\text { mineral resources }\end{array}$ \\
\hline 11.3 & 12.0 & 1129.2 & 268.6 & 3502.7 \\
\hline
\end{tabular}

Due to a more than two-fold decrease in production, as well as construction of wastewater treatment plants over the last two decades, the pollution load to the coastal sea has decreased nearly two-fold. Still, in Estonia the generation of hazardous waste per capita in a year (6.4 tons in 2008) is the highest among European countries [20], which is mainly due to the oil-shale industry.

Regarding the other pollution sources in North Estonia, two large pulp and paper mills have discharged, either directly or via rivers, to the Gulf of Finland. The Tallinn mill used to have an annual production of about $68000 \mathrm{t}$ of sulphite cellulose, and the Kehra mill produced annually $52000 \mathrm{t}$ of sulphate cellulose. The closing of these mills in the 1990s was largely a result of altered environmental requirements. Today, most pulp mills around the Baltic Sea 
utilize a chlorine-free bleaching process. However, about $50 \%$ of the total organochlorine inputs from pulp mills since the early 1940s still reside in the Baltic Sea - mainly in the bottom sediments [11,21].

On the shore of the Gulf of Finland, a highly specialized chemical and metallurgy plant of Sillamäe (Fig. 1) was established in 1946. For production of nuclear materials, uranium was at first locally mined from dictyonema argillite. In 1970 the plant was switched to processing imported loparite. Uranium enrichment was finished in 1989, since then enrichment of rare metals (such as niobium) continues at AS Silmet. However, since 1959, on the immediate shore of the Gulf of Finland, a 50 ha nuclear waste depository grew. Probably some 1200 tons of uranium, 800 tons of thorium enrichment residuals and other hazardous substances are buried there. The closure and sanitation of the depository in 1998-2008 became one of the highest priority environmental projects over the whole Baltic Sea basin. The leakage through the dam to the sea should be negligible now [22].

\section{Results and discussion}

\subsection{Phenols}

While the general European hazardous substances list includes nonylphenoles and octylphenoles [23], the Estonian list specifically includes 1-basic and 2-basic phenols. The phenols are discharged to the coastal sea of Estonia mainly from oil-shale based chemical industry. Studies of phenol concentrations showed that concentrations of 1-basic phenols (p-, m- and o-cresols; 2,3-, 2,6-, 3,4- and 3,5dimethyl phenols) as well as 2-basic phenols (resorcinol, 5- methyl resorcinol, 2,5-dimethyl resorcinol) are currently low, fluctuating within the range $<0.5-5$ $\mu \mathrm{g} / \mathrm{l}$ in North Estonian river estuaries [15]. However, excessively high concentrations of "phenols" (unspecified) were frequently found in the coastal waters of North Estonia in 1970s and 1980s [6].

A regulation of the Ministry of Social Affairs ("Quality and control requirements to surface and ground water used or intended for use for the production of drinking water" from January 2003) specifies upper limits for different quality classes: class $1-0.001 \mathrm{mg} / \mathrm{l}$, class II $-0.005 \mathrm{mg} / 1$ and class III - $0.1 \mathrm{mg} / \mathrm{l}$. According to these standards, all the studied lower reaches and estuaries of the rivers have belonged to I and II classes in recent years. 0.005 $\mathrm{mg} / \mathrm{l}$ is also the upper limit for the European recreational (bathing) water, which is met by most of the Estonian rivers and beaches during summer months [15].

\subsection{Heavy metals in water, sediments and biota}

Concentrations of trace metals (including so-called heavy metals: $\mathrm{Cu}, \mathrm{Zn}, \mathrm{Hg}$, $\mathrm{Pb}, \mathrm{Cd}$ ) in the seawater have been episodically determined in the Baltic Sea [11], including the Estonian coastal waters [7]. More recently, the following metals are included in EIA, the "extended" list for metals: arsenic (As), cadmium (Cd), chromium $(\mathrm{Cr})$, copper $(\mathrm{Cu})$, mercury $(\mathrm{Hg})$, nickel $(\mathrm{Ni})$, lead $(\mathrm{Pb})$ and zinc $(\mathrm{Zn})$. 
Table 2: Concentrations of dissolved metals $(\mathrm{ng} / \mathrm{kg})$ in the North Atlantic $[24,25]$ and the Baltic Sea [26] along with the factor, showing the elevated Baltic Sea concentrations.

\begin{tabular}{|c|c|c|c|}
\hline Metal & North Atlantic & Baltic Sea & Factor \\
\hline Mercury $(\mathrm{Hg})$ & $0,15-0,3$ & $5-6$ & $\sim 20-40$ \\
\hline Cadmium $(\mathrm{Cd})$ & $4(+/-2)$ & $12-16$ & $\sim 3-4$ \\
\hline Lead $(\mathrm{Pb})$ & $7(+/-2)$ & $12-20$ & $\sim 2-3$ \\
\hline Copper $(\mathrm{Cu})$ & $75(+/-10)$ & $500-700$ & $\sim 7-10$ \\
\hline Zinc $(\mathrm{Zn})$ & $10-75$ & $600-1000$ & $\sim 10-40$ \\
\hline
\end{tabular}

However, in the framework of COMBINE, the status for seawater analyses is still "tentative". Such analyses usually require high-cost instrumentation; the concentrations are extremely low, as is the relative preciseness, while the data scatter is remarkable. In 1980s and 1990s, the typical concentration for dissolved Cd was $0.1-0.3 \mathrm{nmol} / \mathrm{dm}^{3}, 5-15 \mathrm{nmol} / \mathrm{dm}^{3}$ for $\mathrm{Cu}$ and $10-30 \mathrm{nmol} / \mathrm{dm}^{3}$ for $\mathrm{Zn}$ [11], the particulate concentrations being 5-10 fold lower.

Despite some decline in loading, the concentrations in the Baltic Sea are still 3 to 50 times higher than in the North Atlantic (Table 2). Heavy metals can reach the marine environment via the atmosphere, through discharges or natural drainage. As a direct impact, annual emissions from the Baltic Sea countries decreased in 1996-2000, by $26 \%$ for cadmium, $15 \%$ for mercury and lead [22]. Concentrations of $\mathrm{Cd}, \mathrm{Pb}$ and $\mathrm{Zn}$ are on average higher in the south-western parts of the Baltic Sea, where atmospheric deposition is greater. One fifth of the cadmium input to the Baltic Sea comes from atmospheric deposition, carried by the prevailing south-westerly winds. Atmospheric emissions of Estonian power plants have declined from $1 \mathrm{t}$ to $0.7 \mathrm{t}$ in 1997-2000 [8].

Determination of the concentrations in the fish tissues and bottom sediments is more reliable and informative. According to the Estonian hazardous substances monitoring results in 2001-2007, the typical concentrations of $\mathrm{Hg}$ in the herring tissues were $0.02-0.04 \mathrm{mg} / \mathrm{kg}$ (dry weight), $0.4-1.5 \mathrm{mg} / \mathrm{kg}$ for $\mathrm{Cd}$, $0.2-0.3 \mathrm{mg} / \mathrm{kg}$ for $\mathrm{Pb}, 60-100 \mathrm{mg} / \mathrm{kg}$ for $\mathrm{Zn}$ and $4-16 \mathrm{mg} / \mathrm{kg}$ for $\mathrm{Cu}$. All the respective concentrations are generally lower than in $1990 \mathrm{~s}$, but $\mathrm{Cu}$ and $\mathrm{Pb}$ still needs some special attention [9].

In addition to the top of the food-web, persistent contaminants tend to concentrate into sediments of the deeper marine areas (Fig. 2). In that sense, the semi-enclosed Baltic Sea acts as a separate, isolated from the rest of the World Ocean basin with large inputs and only internal sinks. Regarding the metals in the sediments of the Gulf of Finland, also vicinity to the historical pollution source plays an important role. The quality of sediments in the Gulf of Finland has been classified using the criteria by SEQC, the Swedish Environmental Protection Agency (Table 3).

According to this classification, the state of surface sediments in the Gulf of Finland was not satisfactory, especially in the NE and E section of the Gulf of Finland. The sediments were "significantly" or "largely" polluted with heavy 


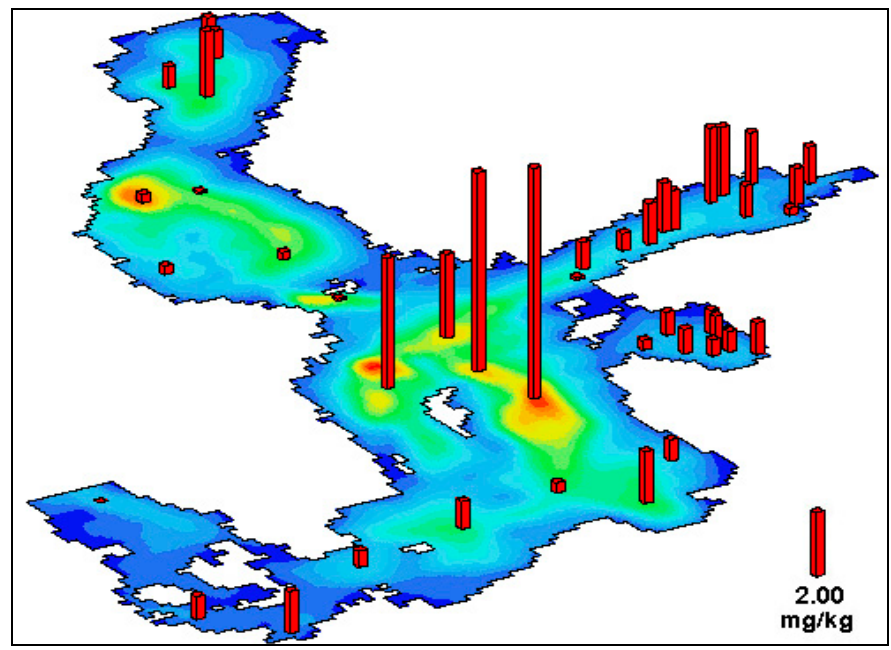

Figure 2: $\quad$ Spatial distribution of heavy metal cadmium in bottom sediments of the Baltic Sea, 0-2 cm layer (modified from [11]).

Table 3: $\quad$ Sediment quality classification (SEQC, mg/kg dry weight [27]).

\begin{tabular}{|c|c|c|c|c|c|}
\hline Metal & $\begin{array}{c}\text { Class 1 } \\
\text { Little/none }\end{array}$ & $\begin{array}{c}\text { Class 2 } \\
\text { Slight }\end{array}$ & $\begin{array}{c}\text { Class 3 } \\
\text { Significant }\end{array}$ & $\begin{array}{c}\text { Class 4 } \\
\text { Large }\end{array}$ & $\begin{array}{c}\text { Class 5 } \\
\text { Very large }\end{array}$ \\
\hline $\mathrm{Pb}$ & $<31$ & $31-47$ & $47-68$ & $68-102$ & $>102$ \\
\hline $\mathrm{Hg}$ & $<0.04$ & $0.04-0.10$ & $0.10-0.27$ & $0.27-0.72$ & $>0.72$ \\
\hline $\mathrm{Cu}$ & $<15$ & $15-30$ & $30-60$ & $60-120$ & $>120$ \\
\hline $\mathrm{Cd}$ & $<0.2$ & $0.2-0.5$ & $0.5-1.2$ & $1.2-3$ & $>3.0$ \\
\hline $\mathrm{Zn}$ & $<85$ & $85-125$ & $125-196$ & $196-298$ & $>298$ \\
\hline $\mathrm{Cr}$ & $<80$ & $80-112$ & $112-160$ & $160-224$ & $>224$ \\
\hline
\end{tabular}

metals. The quality of the sediments surprisingly showed only "slight" or "significant" pollution along North Estonian coast [27]. This difference probably appears as a result of shallower sea with good dilution conditions on one hand, and different industry profiles in Estonia, Russia (St. Petersburg) and Finland (Kotka). According to Perttilä [28], one should bear in mind that over the years, some of these metal deposits will be transformed into hazardous compounds (incl. organic tin and mercury), so their release back into the marine ecosystem may result in very harmful effects.

\subsection{Persistent organic pollutants in river deltas and fish}

The study by Loos and co-authors [29] provides the first EU-wide reconnaissance of the occurrence of polar organic persistent pollutants in European river waters. The selection of sampling sites has done by the participating EU Member States. 122 individual water samples from 27 European countries were analysed for 35 selected compounds $(\mathrm{HCH}, \mathrm{HCB}, \mathrm{PCB}$, 
DDT, PCDD, PCDF, DL-PCB and some more). In that study, only the dissolved (liquid) water phase, and not the suspend material was investigated. The results suggested that just about $10 \%$ of the river water samples could be classified as "very clean" in terms of chemical pollution, since they contained only a few compounds in very low concentrations. The most pristine water samples came from Sweden, Lithuania and Estonia (rivers of Narva, Purtse and Emajõgi) [29].

As persistent organic pollutants tend to accumulate into fats, the primary attention has to be paid to high-fat food, especially fish. The results indicate that the concentrations depends both on location of the catch, but also on fish age, sex, maturity of gonad, fat content and some other characteristics. Also temporal variability can be large $[13,14]$, but generally decreasing trends are visible in some POPs (Figs. 3,4). The dioxin (PCDD) content in fish has been quite well studied in Estonia since 2002. In general, no risk is incurred by consuming perch, pike-perch and flounder. Atlantic salmon, sea trout and eel have not been adequately examined, as their proportion in human consumption is relatively small in Estonia. However, consumption of the "large Baltic herring", older than 5 years and with the length of more than $17 \mathrm{~cm}$, should be avoided or constrained, especially by pregnant women [13].

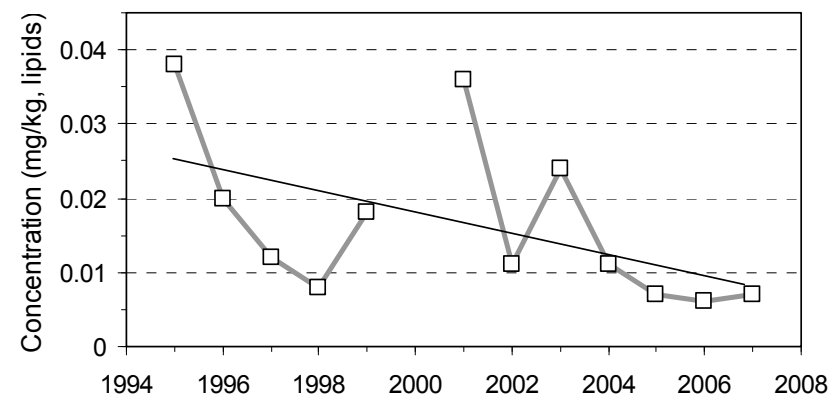

Figure 3: Concentrations of g-HCHs ( $\mathrm{mg} / \mathrm{kg}$ lipids) in the muscle tissues of Baltic herring in the Estonian coastal waters in 1995-2007.

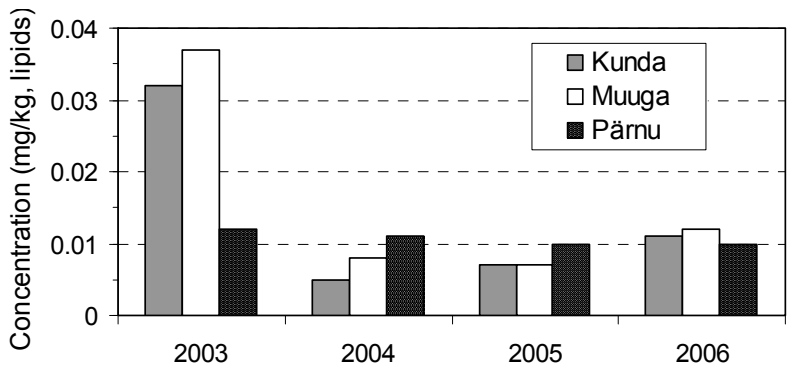

Figure 4: Concentrations of HCBs in the muscle tissues of Baltic herring in different sampling clusters of Estonian coastal sea in 2003-06 $[9,14]$. 


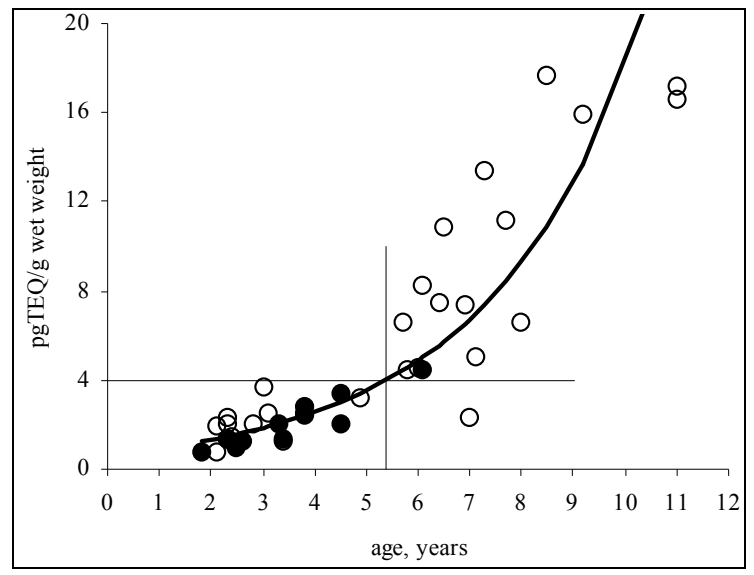

Figure 5: Age-dependent dioxin concentrations in the Baltic herring muscle tissues of Estonian (black circles) and Finnish (white circles) catches [13].

Dioxin concentration grows exponentially with the age (Fig. 5). Currently the age of the Baltic herring in the coastal waters of Estonia is mostly 2-4 years and the proportion of the fish catches older than 5 years is $10 \%[13,14]$. Dioxins could also be found in the bottom sediments. Thus, extensive disturbance of the seabed in the Gulf of Finland by dredging or installing pipelines could result in a massive release of dioxins and other contaminants into the foodweb [28].

\section{Conclusions}

Monitoring programmes of hazardous substance may vary from one country to another, as well as in time. At present, the list of priority hazardous substances of Estonia includes 1-basic and 2-basic phenols, Ba (only in groundwater), heavy metals $(\mathrm{Cr}, \mathrm{Cu}, \mathrm{Ni}, \mathrm{Zn})$ and persistent organic pollutants $(\mathrm{HCH}, \mathrm{HCB}, \mathrm{PCB}$, DDT, PCDD, PCDF, DL-PCB).

The concentrations of hazardous substances in most Estonian surface and coastal waters are currently low. However, as these substances are hardly degradable, they tend to accumulate in bottom sediments and bio-accumulate in food-webs, especially in fat tissues of fish and mammals. Baltic Sea acts as an isolated basin, where large pollution load from surrounding countries could be counteracted mainly by internal sinks. The effect of bans of certain substances, as well as other pollution control mechanisms, is not immediately visible. For instance, due to elevated dioxin and heavy metal concentrations, some fish (large herring, cod) are not advised to eat frequently or in large quantities.

Long-term improvement of the environment quality in North Estonia due to decreased pollution load and self-purification is still evident in recent decades. It also reflects the endorsement of rigid pollution control mechanisms, efficient monitoring and improvement in environmental legislation. 


\section{Acknowledgements}

The study was supported by the ESF grant 7609 and the theme SF0180104s08.

\section{References}

[1] HELCOM. Baltic Sea Action Plan. Adopted on 15 November 2007 in Krakow, Poland by the HELCOM Extraordinary Ministerial Meeting. http://www.helcom.fi/stc/files/BSAP/BSAP_Final.pdf. 2007.

[2] Suursaar, Ü., Aps, R., Kotta, I. \& Roots, O., North-East Estonian coastal sea: recovery from the past anthropogenic pressure and new stressors on the background of natural variability. Ecosystems and Sustainable Development VII. Book Series: WIT Transactions on Ecology and the Environment, 122, WIT Press: Southampton, Boston, pp. 331-342, 2009.

[3] HELCOM. The Fourth Baltic Sea Pollution Load Compilation (PLC-4). Balt. Sea Environ. Proc., 93, 198 pp., 2004.

[4] HELCOM. Hazardous substances of specific concern to the Baltic Sea. Final report of the HAZARDOUS project. Balt. Sea Environ. Proc., 119, 96 pp., 2009.

[5] UNEP. Europe Regional Report 2002. Regionally Based Assessment of Persistent Toxic Substances. UNEP Chemicals: Geneva, 2003.

[6] Suursaar, Ü., Estonian marine monitoring 1968-1991: Results and evaluation. Finnish Marine Research, 262, pp. 123-134, 1994.

[7] Jankovski, H., Simm, M. \& Roots, O., Harmful substances in the ecosystem of the Gulf of Finland. Part I, Trace metals. EMI Report Series, 4, Tallinn, 158 pp., 1996.

[8] Roose, A. \& Roots, O., Monitoring of priority hazardous substances in Estonian water bodies and in the coastal Baltic Sea. Boreal Env. Res., 19, pp. 89-102, 2005.

[9] Simm, M., Hazardous substances in the coastal sea. Estonian Environmental Monitoring 2004-2006, ed. K. Väljataga, Ministry of Environment: Tallinn, pp. 77-79, 2008.

[10] Roots, O., Proposal for selection of national priority hazardous substances for Estonian surface water bodies. Ecological Chemistry. St. Petersburg University and Thesa, 17 (1), pp. 22-34, 2008.

[11] HELCOM. Fourth Periodic Assessment of the State of the Marine Environment of the Baltic Sea Area, 1994-1998. Balt. Sea Environ. Proc., 82B, 218 pp., 2002.

[12] Roots, O., Halogenated environmental contaminants in fish from Estonian coastal areas. Chemosphere, 43 (4-7), pp. 623-632, 2001.

[13] Roots, O., Lahne, R., Simm M. \& Schramm, K.W., Dioxins in the Baltic herring and sprat in Estonian coastal waters. Organohalogen Compounds, 62, pp. 201-203, 2003.

[14] Lukki, T., Roots, O., Simm, M., Talvari, A. \& Tuvikene, A., PCBs, HCHs and HCB in the Baltic Sea herring of the Estonian coastal sea. Organohalogen compounds, 70, pp. 2098-2101, 2008. 
[15] Hannus, M., Leisk, Ü. \& Loigu, E., Hazardous substances in rivers. Hazardous substances in Estonian Environment, eds. A. Roose, E. Otsa, O. Roots, Tartu University Publishing House: Tartu, pp. 35-37, 2003.

[16] Andrejev O., Myrberg K., Alenius P. \& Lundberg P., Mean circulation and water exchange in the Gulf of Finland - a study based on three-dimensional modelling. Boreal Env. Res., 9, pp. 1-16, 2004.

[17] Suursaar, Ü., Aps, R., Martin, G., Põllumäe, A. \& Kaljurand, K., Monitoring of the pulp mill effluents in the coastal waters of North Estonia. Water Pollution I. Book Series: WIT Transactions on Ecology and the Environment, 111, WIT Press: Southampton, Boston, pp. 217-226, 2008.

[18] Ojaveer, E., Simm, M., Balode, M., Purina, I. \& Suursaar, Ü., Experiments on the effect of Microcystis aeruginosa and Nodularia spumigena upon the survival of Eurytremora affinis and fertilization, embryonic and larval development of Baltic herring Clupea harengus membras. Environmental Toxicology, 18 (4), pp. 236-242, 2003.

[19] Raudsep, R., Estonian geo-resources in the European context. Estonian Journal of Earth Sciences, 57, pp. 80-86, 2008.

[20] Rohtla, R. (ed.), Monthly bulletin of Estonian statistics, 12/08. Statistics Estonia: Tallinn, 148 pp., 2009.

[21] Kankaanpää, H., Lauren, M., Saares, R., Heitto, L. \& Suursaar, Ü., Distribution of halogenated organic material in sediments from anthropogenic and natural sources in the Gulf of Finland catchment area. Environmental Science and Technology, 31 (1), pp. 96-104, 1997.

[22] HELCOM. Radioactivity in the Baltic Sea 1992-1998. Balt. Sea Environ. Proc., 85, 102 pp., 2003.

[23] HELCOM. Heavy Metal Pollution to the Baltic Sea in 2004. Balt. Sea Environ. Proc., 108, 33 pp., 2007.

[24] Dalziel, J., Reactive mercury in the eastern North Atlantic and Southeast Atlantic, Marine Chem., 49, pp. 307-314, 1995.

[25] Kremling, K. \& Streu, P., The behaviour of dissolved Cd, Co, Zn, and $\mathrm{Pb}$ in North Atlantic near-surface waters $\left(30^{\circ} \mathrm{N} / 60^{\circ} \mathrm{W}\right.$ to $\left.60^{\circ} \mathrm{N} / 2^{\circ} \mathrm{W}\right)$. Deep Sea Research, 48, pp. 2541-2567, 2001.

[26] Pohl, C. \& Hennings, U., The coupling of long-term trace metal trends to seasonal diffusive trace metal fluxes at the oxic-anoxic interface in the Gotland Basin; (57 $\left.19,20^{`} \mathrm{~N} ; 2^{\circ} 03,00^{\prime} \mathrm{E}\right)$ Baltic Sea. Journal of Marine Systems, 56, pp. 207-225, 2005.

[27] Assessment of Environmental Quality - Coasts and Sea. Naturvårdsverket Rapport, No. 4914, 134 pp., 1999.

[28] Perttilä, M., Kankaanpää, H., Kotilainen, A., Laine, A., Lehtoranta, J., Leivuori, M., Myrberg, K. \& Stipa, T., Implementation of the North European gas pipeline project - data inventory and further need for data for environmental impact assessment. MERI, 58, 22 pp., 2006.

[29] Loos, R., Gawlik, B.M., Locoro, G., Rimaviciute, E., Contini, S. \& Bidoglio, G., EU Wide Monitoring Survey of Polar Persistent Pollutants in European River Waters. European Commission, EUR 23568EN, 2008. 